\title{
A rare cause of virilization; Ovarian steroid cell tumor, not otherwise specified (NOS)
}

\author{
Nadir rastlanilan virilizasyon sebebi; overyan steroid hücreli tümor \\ Nicel Taşdemir', Cem Çelik ${ }^{1}$, Remzi Abalı ${ }^{1}$,Erson Aksu' ${ }^{1}$, Meltem Öznur ${ }^{3}$, Murat Yılmaz ${ }^{2}$ \\ 'Department of Gynecology and Obstetrics, Faculty of Medicine, Namik Kemal University, Tekirdağ, Turkey \\ ${ }^{2}$ Department of Endocrinology and Metabolism, Faculty of Medicine, Namik Kemal University, Tekirdağ, Turkey \\ ${ }^{3}$ Department of Pathology, Faculty of Medicine, Namik Kemal University, Tekirdağ, Turkey
}

\section{Abstract}

Sex cord-stromal tumors account for $5 \%$ of ovarian tumors and $2 \%$ of malignant ovarian tumors. Steroid cell tumors (SCT), not otherwise specified (NOS), are rare sex cord-stromal tumors of the ovary and account for less than $0.1 \%$ of all ovarian tumors. We report a rare case of a postmenopausal woman presented with hirsutism, virilism and with findings of hyperestrogenism. (J Turkish-German Gynecol Assoc 2012; 13: 275-7)

Key words: Hirsutism, steroid cell tumor, virilization, hyperandrogenism, sex cord-stromal tumor

Received: 01 April 2012

Accepted: 23 June 2012

\section{Ozzet}

Sex-cord hücreli tümörler, tüm over tümörlerinin \%5 'ini, malign over tümörlerinin \%2'sini oluşturmaktadır. Steroid hücreli tümörler nadir sex kord -stromal tümörler olup, tüm over tümörlerinin \%0.1'ini oluşturmaktadır. Biz hirsutizm, virilizasyon ve hiperöströjenizm bulguları mevcut postmenapozal bir bayan olgusunu sunmak istedik.

Anahtar kelimeler: Steroid hücreli tümör, virilizasyon, hirsutizm, hiperandrojenizm, sex cord- stromal tümör

(J Turkish-German Gynecol Assoc 2012; 13: 275-7)

Geliş Tarihi: 01 Nisan 2012

Kabul Tarihi: 23 Haziran 2012

\section{Introduction}

Sex cord-stromal tumors account for $5 \%$ of ovarian tumors and $2 \%$ of malignant ovarian tumors $(1,2)$. SCTs account for less than $0.1 \%$ of all ovarian tumors (3). The terms 'lipid cell tumor' and 'lipoid cell tumor' have been used to designate a group of morphologically similar ovarian neoplasms of diverse cellular origin. These tumors are composed exclusively of cells-i.e., lutein cells, leydig cells, and adrenal cortical cells. The use of the above terms is misleading, however, as some tumors in this category contain little or no lipid. In view of this inaccuracy, the term 'steroid cell tumor' is proposed for these neoplasms, which can be divided into several subtypes according to their cells of origin. The designation 'steroid cell tumor' is appropriate not only because of the morphological features of the neoplastic cells, but also because of their propensity to secrete a variety of steroid hormones that often produce characteristic clinical syndromes (3). We report a rare case of postmenopausal woman presenting with hirsutism, virilism and also findings of hyperestrogenism.

\section{Case Reports}

A 51-year-old, gravida 5, para 4, abortus 1 woman (age of onset of menopause 42 years) presented with rapidly pro- gressing hirsutism, receding hairline, male-pattern baldness, alopecia and voice deepening (Figure 1). She was diagnosed with hypertension for six years and diabetes mellitus for seven years. She had had a laparoscopic cholecyctectomy operation 3 years earlier and she was diagnosed for depression 2 years previously. Physical examination revealed hirsutism involving the face, chin, upper back, chest, upper and the lower abdomen giving a score of 44 from modified Ferriman and Gallwey scoring system (Figure 2). Gynecologic examination revealed cliteromegaly which had developed over the past 6 years.

Pelvic ultrasound-scan revealed a solid ovarian tumor of $35 \times 36 \mathrm{~mm}$ in the left ovary. Markedly elevated serum testosterone level $(8.3 \mathrm{ng} / \mathrm{mL})$, elevated serum estradiol level $(85.86 \mathrm{pg} / \mathrm{mL})$ and suppressed gonadotrophin levels (FSH: $0.606 \mathrm{mIU} / \mathrm{mL}, \mathrm{LH}<0.01 \mathrm{mIU} / \mathrm{mL}$ ) were observed. Dehydroepiandrosteronesulfate level was normal $(131.4 \mu \mathrm{g} /$ $\mathrm{dL}$ ). The levels of tumor markers were normal. Computed tomography and magnetic resonance imaging of the abdomen and pelvis revealed a $40 \times 25 \mathrm{~mm}$ solid tumor in the left adnexia. Adrenal glands were normal. The patient underwent total abdominal hysterectomy bilateral salpingo-oophorectomy. Frozen section of the left ovary revealed thecoma. Gross pathological examination of the left ovary revealed an $3 \times 2.2 \mathrm{~cm}$ well-circumscribed, yellow-orange mass. In the uterine cavity a $0.6 \times 0.8 \mathrm{~mm}$ endometirial polyp was observed. 


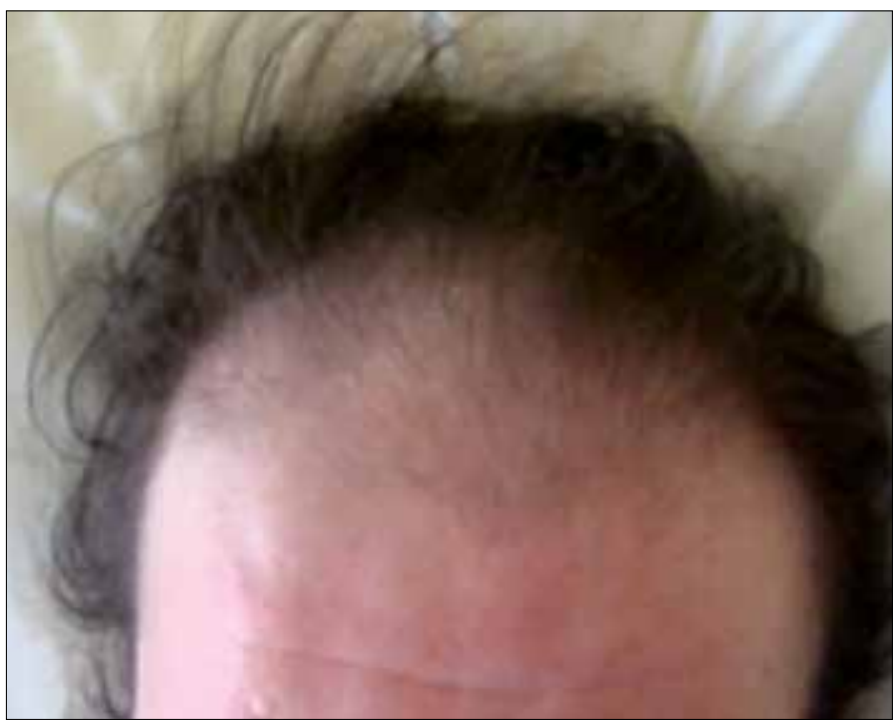

Figure 1. Findings of virilism. Male pattern baldness

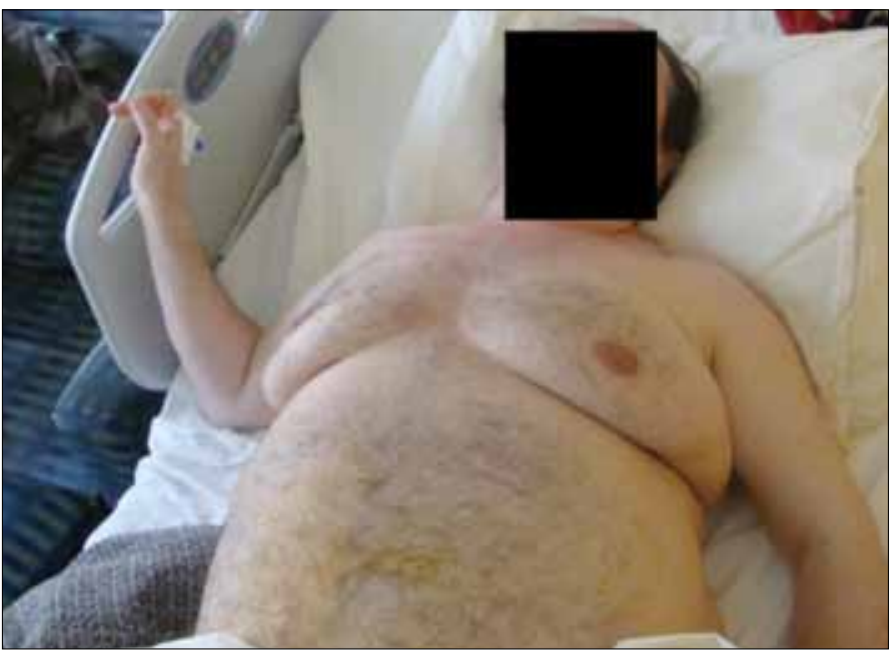

Figure 2. Hirsutism involving the face, chin, upper back, chest, upper and the lower abdomen giving a score of $\mathbf{4 4}$ from modified Ferriman and Gallwey scoring system

Microscopic examination revealed steroid cell tumor, not otherwise specified for the mass in the left ovary and endometrial proliferative findings with endometrial polyp for the uterus. Total testosterone level was normal on the postoperative first month.

\section{Discussion}

Ovarian SCTs account for $0.1-0.2 \%$ of all ovarian tumors, and usually present with the findings of virilization $(3,4)$. There are three subtypes: stromal luteoma, Leydig-cell tumor, and steroid cell tumor, not otherwise specified (NOS). Steroid cell tumors, NOS, must be distinguished from other tumors in the steroid cell category -luteinized thecomas, pregnancy luteomas and carcinomas, both primary clear cell carcinoma and metastatic renal cell carcinoma. Both the hilus cell tumor and the rare Leydig cell tumor, nonhilar type, can be identified with certainty only by demonstrating the presence of crystals of Reinke in the cytoplasm of the neoplastic cells (5-8). Since testicular Leydig cell tumors lack these inclusions in $60-65 \%$ of cases $(9,10)$, an unknown proportion of tumors in the steroid cell tumor, NOS, category are almost certainly Leydig cell tumors in which crystals have not been identified. The luteinized thecoma can be identified by the presence of a predominant spindle cell background. It is posible, however, that the steroid cell tumor, NOS, is a fully luteinized thecoma (11), since some luteinized thecomas show extensive luteinization $(8,12)$ and a rare steroid cell tumor, NOS, contains small areas of spindle cell proliferation (13). The focal presence of nonluteinized granulosa cells in a predominantly luteinized granulosa cell tumor helps to distinguish it from a steroid cell tumor. Electron-microscopical examination of the tumor may be of additional help in distinguishing a steroid cell tumor from a clear-cell carcinoma by demonstrating the typical abundant smooth endoplasmic reticulum in the cytoplasm of the neoplastic steroid cells (14). Steroid cell tumor, not otherwise specified, accounts for $60 \%$ of SCTs, $25-45 \%$ of which are clinically malignant. This subtype is associated with androgenic changes. SCTs often present as unilateral solid tumors but the size of tumors may be as small as $2-3 \mathrm{~cm}$, thus it would be difficult to diagnose. Clinical and laboratory findings are usually exaggerated according to its dimension. Several medications such as oral contraceptives, cyproteroneacetate and spironolactone were prescribed for the presented case for hirsutism for 2 years. Also laser hair removal treatment was performed. However, symptoms of virilization did not improve. Delayed diagnosis would be important for the tumors with malignant potential. Interestingly, pathologically benign tumors can behave in a clinically malignant fashion.

Estradiol secretion by these tumors is not uncommon (6-23\%) (15). The presented case had endometrial hyperplasia and polyp as a result of elevated estradiol level. Excess estrogen production can result in menorrhagia, postmenopausal bleeding and rarely adenocarcinoma. SCTs should be kept in mind for the patients presenting with virilization and high serum androgen level. Meticulous clinical evaluation should be carried out before initiation of medical therapy for such patients.

\section{Conflict of interest}

No conflict of interest was declared by the authors.

\section{References}

1. Case records of the Massachusetts General Hospital. Weekly clinicopathological exercises. Case 22-1982. A nine-year-old girl with virilization and a calcified pelvic mass. N Engl J Med 1982; 306: 1348-55.

2. Dunnihoo DR, Grieme DL, Woolf RB. Hilar-cell tumors of the ovary. Report of 2 new cases and a review of the world literature. Obstet Gynecol 1966; 27: 703-13.

3. Hartman LC, Young RH, Evans MP, Podratz KC: in WJ Hoskins, CA Perez, RC Young: Principles and Practice of Gynecologic Oncology, 2nd ed, Philadelphia, Lippincott-Raven, 1997; pp. 1015-9.

4. Mehdi G, Ansari HA, Sherwani RK, Rahman K, Akhtar N. Ovarian steroid cell tumour: correlation of histopathology with clinicopathologic features. Patholog Res Int 2011: 987895. 
5. Hayes MC, Scully RE. Ovarian steroid cell tumors (not otherwise specified). A clinicopathological analysis of 63 cases. Am J Surg Pathol 1987; 11: 835-45. [CrossRef]

6. Hughesdon PE. Lipid cell thecomas of the ovary. Histopathology 1983; 7: 681-92. [CrossRef]

7. Kim I, Young RH, Scully RE. Leydig cell tumors of the testis. A clinicopathological analysis of 40 cases and review of the literature. Am J Surg Pathol 1985; 9: 177-92. [CrossRef]

8. Koss LG, Rothschild EO, Fleisher M, Francis JE Jr. Masculinizing tumor of the ovary, apparently with adrenocortical activity. A histologic, ultrastructural, and biochemical study. Cancer 1969; 23: 1245-58. [CrossRef]

9. Mostofi FK, Price EB. Tumors of the male genital system.(Atlas of tumor pathology; 2nd ser;fasc 8.) Washington D.C.: Armed Forces İnstitute of Tumor Pathology 1973: 86-99.

10. Roth LM, Sternberg WH. Ovarian stromal tumors containing Leydig cells. II. Pure Leydig cell tumor non-hilar type. Cancer 1973; 32: 952-60. [CrossRef]
11. Roth LM, Sternberg WH. Partly luteinized theca cell tumor of the ovary. Cancer 1983; 51: 1967-704. [CrossRef]

12. Sachs BA, Spiro D. Leydig (sympathicotrophic) cell tumor of the ovary: report of a case with virilism including postmortem findings. J Clin Endocrinol Metab 1951; 11: 878-89. [CrossRef]

13. Scully RE. Tumors of the ovary and maldeveloped gonads. Atlas of tumor pathology. Second series. Fascicle 16. Armed Forces Institute of Pathology, Washington 1979; 246-62.

14. Zhang J, Young RH, Arseneau J, Scully RE. Ovarian stromal tumors containing lutein or Leydig cells (luteinized thecomas and stromal Leydig cell tumors)--a clinicopathological analysis of fifty cases. Int J Gynecol Pathol 1982; 1: 270-85. [CrossRef]

15. Varras M, Vasilakaki T, Skafida E, Akrivis C. Clinical, ultrasonographic, computed tomography and histopathological manifestations of ovarian steroid cell tumour, not otherwise specified: our experience of a rare case with female virilisation and review of the literature. Gynecol Endocrinol 2011; 27: 412-8. [CrossRef] 